University of Wollongong

Research Online

Faculty of Engineering - Papers (Archive)

Faculty of Engineering and Information

Sciences

$1-1-2009$

\title{
Hybrid fuel cell and energy storage systems using superconducting coil or batteries for clean electricity generation
}

Danny Soetanto

University of Wollongong, soetanto@uow.edu.au

Kai Ding

Hong Kong Polytechnic University

Follow this and additional works at: https://ro.uow.edu.au/engpapers

Part of the Engineering Commons

https://ro.uow.edu.au/engpapers/523

\section{Recommended Citation}

Soetanto, Danny and Ding, Kai: Hybrid fuel cell and energy storage systems using superconducting coil or batteries for clean electricity generation 2009, 365-368.

https://ro.uow.edu.au/engpapers/523

Research Online is the open access institutional repository for the University of Wollongong. For further information contact the UOW Library: research-pubs@uow.edu.au 


\section{Hybrid Fuel Cell and Energy Storage Systems Using Superconducting Coil or Batteries for Clean Electricity Generation}

\author{
D. Sutanto, Senior Member, IEEE \\ School of Electrical, Computer and Telecommunications \\ Engineering, University of Wollongong \\ Wollongong, Australia \\ soetanto@uow.edu.au
}

\author{
Kai Ding \\ Department of Electrical Engineering \\ Hong Kong Polytechnic University \\ Hong Kong, China
}

\begin{abstract}
This paper described a novel design of a hybrid fuel cell and energy storage system using high temperature superconducting energy storage system (HT-SMES) or batteries to meet fast changing load. The power electronic switches in the converter of the energy storage system are controlled in such a way that the amplitude and waveform of the inverter output current from the fuel cell is tightly regulated to follow a sinusoidal reference waveform. In this way, the energy storage system is used to supply the fast changing part of the load and the fuel cell system continuously supplies a constant full load demand. The SABER simulation results during motor starting will be presented and discussed.
\end{abstract}

Keywords-PEM fuel cell; dc-dc; inverte; motor startin; energy storage system; battery

\section{INTRODUCTION}

Proton Exchange Membrane [PEM] fuel cell rated between 50 Watts and $5 \mathrm{~kW}$ are now commercially available for use in generating electricity in residential and industrial buildings. Recent investigation has already shown that fuel cell has a poor response to fast changing load [1]. The chemical reaction of the fuel cell system is too slow to follow any fast changing load. Further, with the increasing use of power electronics to improve appliance and motor efficiency, the waveform of load can be distorted and contains harmonics, which can also pose a problem to a fuel cell power system.

In this paper, a SABER model for a $500 \mathrm{~W}$ commercial PEM fuel cell (H-Power Epac-500-1), including the models of the PEM fuel cell, the full bridge DC/DC boost converter and the output single-phase inverter have been formulated. To simulate the fast changing load, a transient model of a single phase ac induction motor has also been developed and incorporated into the SABER model of the PEM fuel cell system. The inverter output drops significantly when the induction motor is starting, leading to the under-voltage protection of the motor. To overcome this problem, the paper will describe a new hybrid fuel cell and energy storage system using battery banks or High Temperature Superconducting Magnetic Energy Storage System (HTSMES). The proposed control system of such a hybrid system will be discussed which allows for a tight control of the output current of the fuel cell inverter irrespective of the speed of the load variation. This results in a very robust ac system that can even supply highly distorted current waveform due to the possible use of an adjustable ac drive for the induction motor. The very fast power response of the energy storage system complements the slow response of the fuel cell system when faced with fast changing load.

\section{PEM FUEL CELL MODEL}

Although there are many PEM fuel cell models in [2-4], they are generally complex and involve many chemical reaction equations. In order to obtain a practical electrical PEM fuel cell model, a generic behavioral SABER electrical model of a PEMFC stack is formulated [5]. The parameters of the model for H-Power Epac-500-1 PEM fuel cell are estimated using fitting algorithm from steady-state and transient response experimental test results. Five groups of experimental data were collected in the steady-state test as shown in Fig. 1 and the transient step response results are given in Fig. 2. The simulation results from the SABER model of the H-Power Epac-500-1 PEM fuel cell after the fitting process are shown in Fig. 2 and Fig. 3. As can be seen from the results, the simulation results matched the experiment test very well. The model has also been tested for many other operating conditions and found to always accurately reflect the experimental results. Therefore, the fuel cell SABER model can now be used with confidence in the following sections.

\section{Fuel Cell Power Conditioning System to Meet CONSTANT LOAD}

\section{A. Operating Point Selection}

As shown in the V-I characteristics of Fig. 1, near the point (45 V, 7.7 A), the output voltage changes very little with the output current variation. The output power at this point is near $360 \mathrm{~W}, 72 \%$ of the total power. So, the point $(45 \mathrm{~V}, 7.7 \mathrm{~A})$ is suitable to be selected as the operating point of the PEM fuel cell. Maximum power of $500 \mathrm{~W}$ requires an output current of 11.7 A and an output voltage of $42.7 \mathrm{~V}$. 


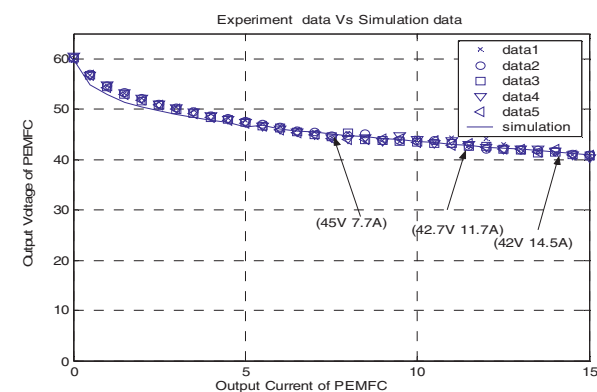

Figure 1. Steady-state experimental test VS simulation test.

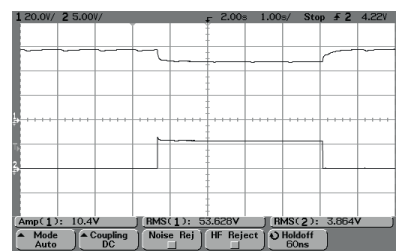

Figure 2. Experiment results for transient response test; load changes from $\infty$ to $7.6 \Omega$ and then back to $\infty$; (Upper) Output Voltage; (Lower) Output Current.

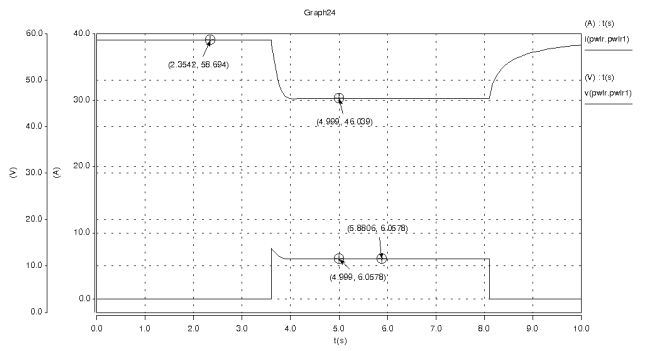

Figure 3. Simulated waveform for transient response test, resistor load changes from $\infty$ to $7.6 \Omega$ and then back to $\infty$; (Upper) Output Voltage; (Lower) Output Current.

So the nominal operating voltage of the fuel cell is $45 \mathrm{~V}$, the nominal and maximum operating current of fuel cell are 7.7 $\mathrm{A}$ and 11.7 A respectively. Point (42 V, $14.5 \mathrm{~A})$ shows the peak power working point. The specification of the design is shown in Table I.

\section{B. DC-DC Boost Converter Plus Inverter to Meet Constant Load}

The objective of the Fuel cell power conditioning system is to take low-voltage $40-60 \mathrm{~V}$ PEMFC output and convert it to $50 \mathrm{~Hz}$ AC $220 \mathrm{~V}$ output that is capable of continuous rating. The system is usually divided into 2 sections: (1) DC-DC converter that boosts the fuel cell to high voltage bus, (2) DCAC inverter produces $50 \mathrm{~Hz}, 220$ volt RMS outputs.

The DC/DC converter boosts the low-voltage of $40-60 \mathrm{~V}$ from the PEM fuel cell to $380 \mathrm{~V}$ high voltage bus. The full bridge topology, shown in Fig. 4, was chosen for the DC/DC converter design because it offers the best distribution of switch stresses, good controllability of duty cycle/boost ratio, and is a well known robust design that scales well to high power [6].
TABLE I. FUEL CELL CONVERSION SYSTEM ELECTRICAL SPECIFICATION

\begin{tabular}{|l|l|}
\hline $\begin{array}{l}\text { Operating Voltage } \\
\text { (40V to 60V) }\end{array}$ & $45 \mathrm{~V}$ Nominal Regulated \\
\hline Operating Current & 7.7 A Nominal, 11.7 A max. \\
\hline Power at 11.7A & $500 \mathrm{~W}$ \\
\hline Peak Power & $550-600 \mathrm{~W}$ \\
\hline
\end{tabular}

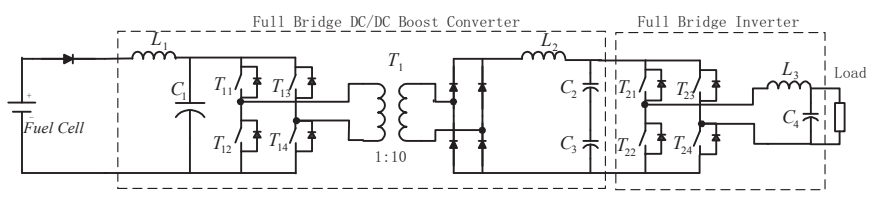

Figure 4. PEM fuel cell power conditioning system.

The maximum boost ratio is $450 / 40$ or $11.25 \mathrm{X}$, Minimum boost ratio is $311 / 60$ or $5.18 \mathrm{X}$, in the design, the transformer ratio was selected as 1:10, input filter: inductor of $10 \mu \mathrm{H}$, capacitor of $120 \mathrm{mF}$, output filter inductances: $\mathrm{L}_{2}, \mathrm{~L}_{3}$ of 150 $\mu \mathrm{H}$ each and the capacitors $\mathrm{C}_{2}, \mathrm{C}_{3}$ of $500 \mu \mathrm{F}$ each. The phaseshift PWM modulation method and PI controller were employed to control the $\mathrm{DC} / \mathrm{DC}$ boost converter. A singlephase full bridge inverter is selected for this application as shown in Fig. 4. For the output filter the following components were used: $\mathrm{L}_{3} 1.25 \mathrm{mH}, \mathrm{C}_{4} 40 \mu \mathrm{F}$. Instant voltage feedback and PID controller were employed in the inverter control.

Fig. 5 shows the simulation results of the output voltage and current when feeding a $360 \mathrm{~W}$ load. An ac current source with amplitude $2.27 \mathrm{~A}$ in phase with inverter output voltage was selected as the load as shown in the fourth plot in Fig. 6. The first plot is the DC output voltage of the boost converter with an average value of $379.96 \mathrm{~V}$. The second plot is the output voltage of the PEM fuel cell, the voltage at steady-state is near $44.7 \mathrm{~V}$, the third plot is the output current drawn from the PEM fuel cell with an average value near $8 \mathrm{~A}$ during steady-state. As can be seen from the simulation waveforms, the current drawn from the PEM fuel cell is a DC current with ripples. The steady-state working point of the simulation is near $(44.7 \mathrm{~V}, 8 \mathrm{~A})$.

\section{INDUCTION MOTOR STARTING}

An approximate equivalent circuit on a per-phase basis of a balanced three-phase induction motor is shown in Fig. 6 [7].

At the time of starting, the rotor speed is zero and the perunit slip (s) is unity. Therefore, the starting current, from Fig. 7 , is

$$
\tilde{I}_{2 s}=\frac{\tilde{V}_{1}}{R_{e}+j X_{e}}
$$

where $R_{\mathrm{e}}=R_{1}+R_{2}$ and $X_{\mathrm{e}}=X_{1}+X_{2}$.

Since the effective rotor resistance, $R_{2} / s$, is very small at the time of starting compared with its value at rated slip, the starting current may be as much as $400 \%$ to $800 \%$ of the fullload current, leading to an excessive line voltage drop [9]. 


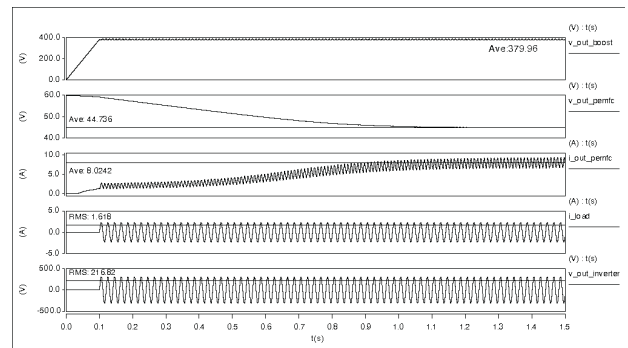

Figure 5. Simulation measurements of the fuel cell conversion system when feeding a $360 \mathrm{~W}$ ac current load.

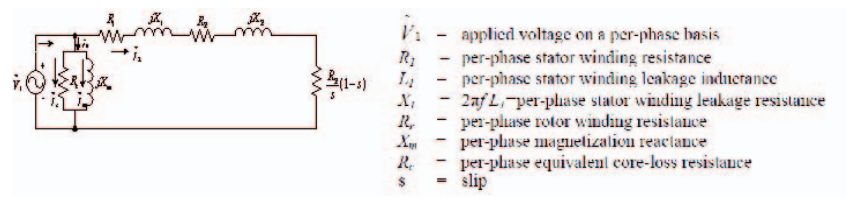

Figure 6. An approximate equivalent circuit on a per-phase basis of a balanced three-phase induction motor.

\section{Problem DURING MOtor StARTING}

The sudden large increase in current drawn from the fuel cell stack will cause significant drop of the DC voltage of the fuel cell, which may damage the stack. Further, this will cause the ac output of the inverter to drop accordingly which may cause the tripping of the ac motor circuit breaker. When the fuel cell system as shown in Fig. 4 is connected to an ac induction motor, the simulation results during motor starting are shown in Fig. 7 and Fig. 8. The current amplitude at time 0.8 second is five times the steady state current as shown in the fourth plot in Fig. 5. As can be seen from the simulation results, a large current is drawn from the fuel cell causing severe voltage collapse. Means must be provided to overcome this problem.

\section{SOlution Using EnERgy Storage System}

As shown in Fig. 8, the sluggish response of the fuel cell to a sudden load change means that an additional energy storage element is needed to handle the load transients. Several papers on the use of an energy storage for dynamic performance of power systems have been recently published [8,9], showing that Energy Storage System using either battery or superconducting magnetic energy storage can help in the operation of power systems, by providing active and reactive power support, emergency supply, active filtering, increased damping against transient stability and fast dynamic control of active and reactive flow in a transmission corridor. One main advantage of the storage energy systems is its fast response to load changes. Batteries and superconducting magnetic energy storage can response to load changes in micro-seconds and since the rating is in $\mathrm{kWh}$, in a short period, a large amount of $\mathrm{kW}$ can be generated in excess of its steady state rating. In this paper, an energy storage system using either superconducting coil or battery is used, as shown in Fig. 9. The purpose of the energy storage system is to control the magnitude and waveform of the output current of the fuel cell inverter to be sinusoidal with constant amplitude in phase with the output voltage of the inverter.

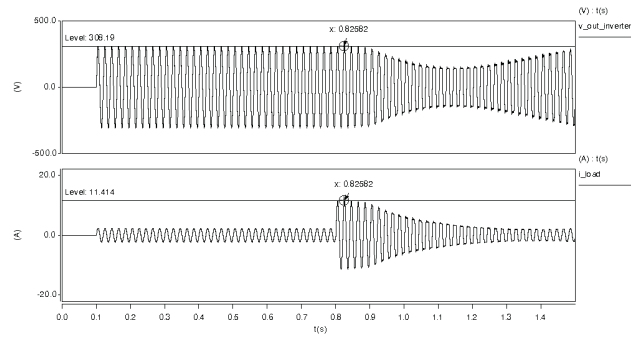

Figure 7. Output voltage of the inverter and load current.

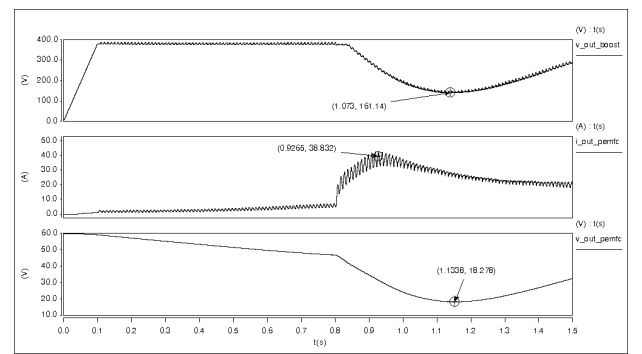

Figure 8. The DC output voltage of Boost converter and the fuel cell output current and voltage.

The difference between the controlled current in the fuel cell and the load current is supplied by the energy storage system. Because the waveform is tightly controlled to be sinusoidal, the proposed hybrid system is suitable for use with highly distorted load due to the use of adjustable speed drive for the induction motor. In order to simplify the control of the energy storage system, a hysteresis band controller is used to control the inverter output current $i_{s}$ to be sinusoidal. The actual current, $i_{\mathrm{s}}$, is compared with the band around the reference current. If the actual current $i_{s}$ in Fig. 10 tries to go beyond the upper band, the current is made to reduce in value by the appropriate power electronics switching action. The opposite switching occurs if the actual current tries to go below the lower band.

SABER simulation is carried out using the proposed method. An ac current with amplitude $2.27 \mathrm{~A}$ in phase with the inverter output voltage is used as the reference of the inverter output current. The current waveform drawn by the load is shown in the plot 3 of Fig. 11. The DC voltage of the battery $\mathrm{VB}$ is $400 \mathrm{~V}, L_{\mathrm{F}}=5 \mathrm{mH}$. The SABER simulation results are shown in Fig. 11 and Fig. 12. The fuel cell inverter output current shown in the second plot of Fig. 11 is the single phase inverter output current.

As can be seen from the results, although the load current shown in the third plot of Fig. 11 draw a very large current during the time $0.8 \mathrm{~s}$ to $1.2 \mathrm{~s}$, the inverter output current, is still regulated and maintained to be sinusoidal and with constant magnitude, the extra large current needed by the load is supplied by the energy storage system as shown in the fourth plot of Fig. 11. DC output of the boost converter and the fuel cell output voltage are shown in Fig. 12. The fuel cell system always works near its optimum working point $(44.2 \mathrm{~V}, 8.9 \mathrm{~A})$. The simulation results show that the problem with motor starting can be solved by using the proposed hybrid fuel cell and energy storage power system. 


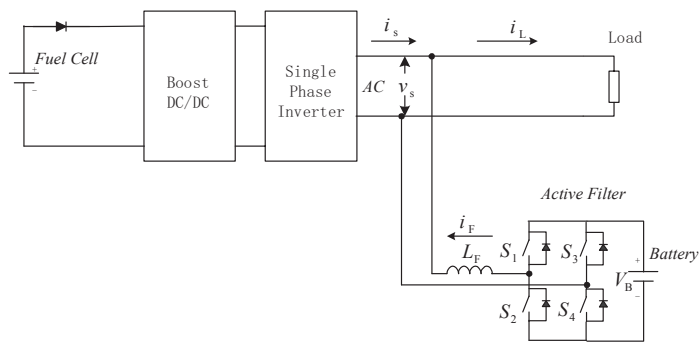

(a)

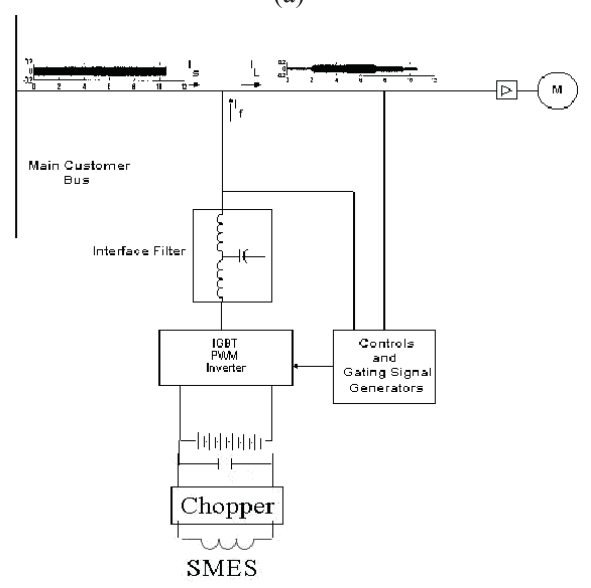

(b)

Figure 9. Hybrid fuel cell and energy storage system: (a) using battery banks, (b) using superconducting magnetic energy storage (SMES).

\section{CONCLUSION}

This paper proposes a hybrid fuel cell and energy storage system. A SABER model for the commercially available $\mathrm{H}$ Power Epac-500-1 Fuel cell is developed.

The fuel cell power conditioning system using a full bridge boost converter and a full bridge single-phase inverter is presented. Fast changing load is represented by the starting transient of an ac induction machine. The problem encountered when the fuel cell system is used during the motor starting operation is discussed. The SABER simulation results of the voltages and currents of a fuel cell system during motor starting are shown and discussed.

The results confirm that fuel cell system without energy storage element cannot be used for motor starting. To solve this problem, it is proposed to use a hybrid fuel cell and an energy storage power system, either in the form of a high temperature superconducting magnetic energy storage system or a battery energy storage system. Hysteresis control is used for the energy storage system to ensure that the fuel cell sees a constant load and continuously work at its optimum operating point and all the variation of load is supplied from the energy storage system. This has the advantages of increasing the fuel cell operating life and increase efficiency. The simulation results of the voltages and currents of the hybrid system during motor starting are shown and discussed. The hybrid system is shown to solve the motor starting problem and the fast operation of the energy storage system is a good complement to the relatively slow responding fuel cell system.

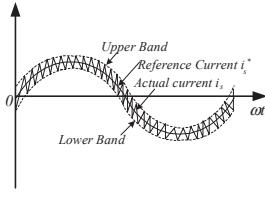

Figure 10. Hysteresis band.

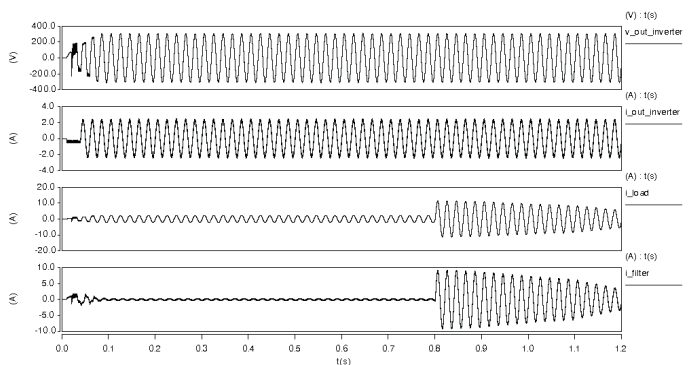

Figure 11. Output voltage and current of the inverter, load current, output current of the energy storage system.

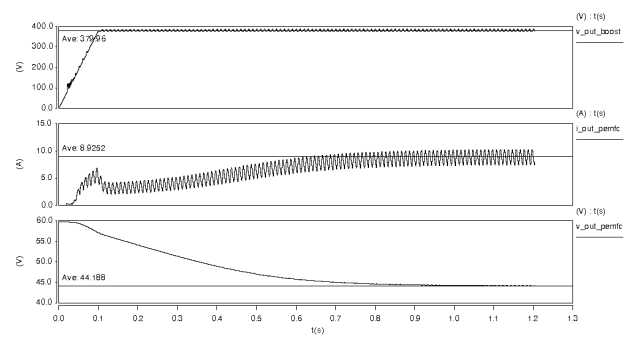

Figure 12. DC output voltage of Boost converter and fuel cell output voltage.

\section{REFERENCES}

[1] R. Lasseter, "Dynamic models for micro-turbines and fuel cells," in IEEE Power Engineering Society Summer Meeting, vol. 2, pp. 761-766, 2001.

[2] W. Caisheng, M. H. Nehrir, and S. R. Shaw, "Dynamic models and model validation for PEM fuel cells using electrical circuits," IEEE Transactions on Energy Conversion, vol. 20, pp. 442-451, 2005.

[3] P. Famouri and R. S. Gemmen, "Electrochemical circuit model of a PEM fuel cell," in IEEE Power Engineering Society General Meeting, vol. 3, pp. 1436-1440, 2003.

[4] D. Yu and S. Yuvarajan, "A novel circuit model for PEM fuel cells," Proc. IEEE Applied Power Electronics Conference and Exposition, vol. 1, pp. 362-366, 2004.

[5] M. H. Rashid, Power electronics: circuits, devices, and applications, 3rd ed. Upper Saddle River: Tom Robbins, 2004.

[6] T. P. Bohn and R. D. Lorenz, "A low-cost inverter for domestic fuel cell applications,” Proc. 2003 Fuel Cell Seminar, Miami, Florida, 2003.

[7] S. J. Chapman, Electric machinery fundamentals, 2nd ed., New York: McGraw-Hill Inc., 1991.

[8] M. W. Tsang and D. Sutanto, "A fuzzy-based controller using battery energy storage system to enhance power system damping," Journal of Electrical and Electronics Engineering, Australia, vol. 19, pp. 37-43, 1999.

[9] M. V. Aware and D. Sutanto, "Improved controller for power conditioner using high-temperature superconducting magnetic energy storage (HTS-SMES)," IEEE Transactions on Applied Superconductivity, vol. 13, pp. 38-47, 2003. 